\title{
Keragaan Karakter Pembungaan Kuantitatif dan Profil Metabolomik Bawang Merah (Allium cepa var. aggregatum) yang Diinduksi dengan Perlakuan Vernalisasi
}

\author{
The characteristic Performace of Quantitative Flowering Characters and \\ Metabolomic Profile of Shallot (Allium cepa var. aggregatum) Induced by Vernalization
}

\author{
Marlin $^{1.2}$, Awang Maharijaya ${ }^{3.4}$, Sobir $^{3.4}$, dan Agus Purwito ${ }^{3 *}$
}

Diterima 16 Agustus 2017/Disetujui 15 Oktober 2018

\begin{abstract}
Flowering initiation is regulated by the internal and external condition of plant. Vernalization is considered to induce flower initiation on shallots (Allium cepa var. aggregatum). This research objective was to analyze the flowering quantitatif characters and metabolomic profile of shallot during vernalization on bulb development. Vernalization was carried out at $8^{\circ} \mathrm{C}$ for 6 weeks treatment were four bulb growth stage i.e non-vernalized bulbs $\left(S_{0}\right)$, vernalization on embryonic stage $\left(S_{1}\right)$, vernalized bulbs on $1 \mathrm{~cm}$ of shoot stage $\left(S_{2}\right)$ and vernalized bulbs on $2 \mathrm{~cm}$ of shoot stage $\left(S_{3}\right)$. Vernalization treatment in early stage increased the number of tillers, number of umbel, diameter of umbel and percentage of flowering compared to another stage. The early stage of bulbs growth was the effective stage in receiving vernalization treatment. The bigger number and diameter of umbel lead to the higher percentage of flowering in shallot plant. The number and diameter of umbel can be used as character of selection for the percentage flowering character in shallot. Metabolomic analysis has identified of 104 specific metabolites from different vernalization treatments and clustered shallot into three groups. The early stadium of bulbs development (embryo stadia and stadia $1 \mathrm{~cm}$ buds) contains specific metabolomes (phytol and 2-propanone) as the indicator of reproductive phase.
\end{abstract}

Keywords: correlation, flower induction, hierarchical cluster analysis, metabolomic

\begin{abstract}
ABSTRAK
Proses pembungaan pada bawang merah (Allium cepa var. aggregatum) sangat dipengaruhi faktor internal dan eksternal tanaman. Induksi pembungaan dengan perlakuan vernalisasi dilakukan untuk mendorong inisiasi pembentukan bunga bawang merah. Penelitian bertujuan untuk menganalisis karakter kuantitatif pembungaan dan profil metabolomik bawang merah yang diberikan perlakuan vernalisasi pada stadia perkembangan umbi. Vernalisasi dilakukan pada suhu $8{ }^{\circ} \mathrm{C}$ selama 6 minggu terdiri atas empat taraf, yaitu umbi tanpa vernalisasi $\left(\mathrm{S}_{0}\right)$, vernalisasi pada stadia embrio $\left(S_{1}\right)$, vernalisasi pada stadia tumbuh tunas $1 \mathrm{~cm}\left(S_{2}\right)$, dan vernalisasi pada stadia tumbuh tunas $2 \mathrm{~cm}$ $\left(\mathrm{S}_{3}\right)$. Perlakuan vernalisasi pada stadia awal pertumbuhan umbi mampu meningkatkan karakter jumlah anakan, jumlah umbel, diameter umbel, dan persen berbunga bawang merah dibandingkan vernalisasi pada stadia lainnya. Stadia awal pertumbuhan umbi merupakan stadia terbaik dalam menerima perlakuan vernalisasi. Semakin besar jumlah umbel dan diameter umbel semakin meningkatkan persen berbunga bawang merah. Karakter jumlah umbel dan diameter umbel dapat digunakan sebagai karakter seleksi untuk peubah persen berbunga bawang merah. Analisis metabolomik berhasil mengidentifikasi 104 metabolit spesifik dan mengelompokkan bawang merah menjadi 3 kelompok stadia. Vernalisasi pada stadia awal perkembangan umbi (stadia embrio dan tunas $1 \mathrm{~cm}$ ) menunjukkan adanya perubahan fase reproduktif, yang dicirikan dengan adanya senyawa phytol dan 2-propanone.
\end{abstract}

Kata kunci: metabolomik, analisis pengelompokan hierarkis, induksi pembungaan, korelasi

\footnotetext{
${ }^{1}$ Jurusan Budidaya Pertanian, Fakultas Pertanian, Universitas Bengkulu,

J1. WR. Supratman Kandang Limun, Bengkulu - 38371

${ }^{2}$ Program Studi Pemuliaan dan Bioteknologi Tanaman,

Sekolah Pascasarjana, Institut Pertanian Bogor

${ }^{3}$ Departemen Agronomi dan Hortikultura, Fakultas Pertanian, Institut Pertanian Bogor

J1. Meranti, Kampus IPB Darmaga, Bogor 16680, Indonesia

${ }^{4}$ Pusat Kajian Hortikultura Tropika, Institut Pertanian Bogor

E-mail : marlin@unib.ac.id (*Penulis korespondensi)
} 


\section{PENDAHULUAN}

Bawang merah (Allium cepa var. aggregatum) merupakan tanaman sayuran penting di Indonesia. Bawang merah termasuk dalam kelompok tanaman Allium bersama 780 spesies Allium lainnya (Friesen et al., 2006). Bawang merah dapat dimanfaatkan sebagai sayuran, rempah, dan juga sebagai tanaman obat untuk berbagai jenis penyakit. Bawang merah mengandung essential oil yang berfungsi sebagai antioksidan (Mnayer et al., 2014), dan antikanker (Omar dan Al-Wabel, 2010).

Regulasi kemampuan berbunga tanaman dipengaruhi oleh faktor eksternal dan internal (Yang et al., 2016). Proses pembungaan tanaman dapat diinduksi dengan menyediakan kondisi optimum yang mendukung proses pembungaan. Susanto et al. (2016) menginduksi pembungaan pada tanaman jeruk pamelo dengan melakukan strangulasi selama 3 bulan. Elsiddig et al. (2015) menjelaskan bahwa perlakuan vernalisasi diketahui memberikan dampak yang baik terhadap proses pembungaan tanaman. Menurut Handerson et al. (2003) vernalisasi merupakan suatu respon kuantitatif, semakin lama tanaman terpapar oleh suhu rendah maka akan semakin mempercepat proses pembentukan bunga. Penelitian Elsiddig et al. (2015) menunjukkan perlakuan vernalisasi dengan suhu $4-5{ }^{0} \mathrm{C}$ selama 90 hari atau lebih merupakan faktor utama dalam menginduksi pembungaan bawang bombai kultivar Texas Grano. Induksi pembungaan dengan perlakuan vernalisasi merupakan upaya penting untuk dapat meningkatkan kemampuan berbunga pada bawang merah. Peningkatan kemampuan berbunga pada bawang merah menjadi sangat penting dalam upaya perbaikan sifat-sifat penting tanaman bawang merah melalui proses hibridisasi. Belum diketahui saat perkembangan umbi yang tepat untuk diberikan perlakuan vernalisasi yang dapat menginduksi pembungaan bawang merah. Pemberian vernalisasi pada stadia perkembangan umbi yang tepat dapat meningkatkan respon tanaman terhadap perlakuan induksi pembungaan.

Analisis metabolomik merupakan dimensi baru dalam mempelajari sistem biologi, yang dapat menjelaskan lebih jauh mengenai interaksi selular dalam tingkat sel (Tugizimana et al., 2013). Terdapat banyak senyawa metabolit intraselular yang berperan dalam perubahan reaksi biokimia, dan menghubungkan bagian-bagian yang berbeda dari reaksi metabolisme menjadi suatu ikatan jaringan metabolit yang kuat (Nielsen, 2001). Perubahan pola metabolit tanaman merupakan indikasi adanya lingkungan seluler yang dinamis (Sumner et al., 2003), dan reaksi biosintesisnya berperan dalam keragaman enzim yang dihasilkan (Tugizimana et al., 2013). Strategi analisis gas chromatography mass spectrometry (GC-MS) digunakan untuk menganalisis senyawa volatil, dan senyawa terpilih dianalisis secara struktural dengan spektrometri massa yang mentranspos metode GC-MS (Lekshmi et al., 2014). Analisis metabolomik adalah pendekatan yang menjanjikan untuk mempelajari studi komponen bioaktif dalam ekstrak tumbuhan. Perubahan yang terjadi selama proses metabolit dapat menjadi indikasi penting untuk menunjukkan status pertumbuhan dan perkembangan tanaman.

Penelitian ini bertujuan untuk mengetahui karakter kuantitatif pembungaan dan menganalisis profil metabolomik bawang merah yang diberikan perlakuan vernalisasi pada stadia perkembangan umbi. Melalui penelitian ini diharapkan dapat memberikan informasi terkait upaya peningkatan kemampuan berbunga bawang merah, sehingga dapat berguna bagi pengembangan program pemuliaan bawang merah di Indonesia.

\section{BAHAN DAN METODE}

Penelitian dilakukan di Kebun Percobaan Pusat Kajian Hortikultura Tropika (PKHT) Pasir Kuda Bogor dan Laboratorium Pusat Penelitian dan Pengembangan Hasil Hutan (P3HH) Bogor. Penelitian dimulai bulan Februari sampai Juni 2016. Penelitian menggunakan bahan tanam berupa umbi bawang merah varietas Bima Brebes dengan ukuran 5-7 g per umbi. Umbi bawang ditumbuhkan pada beberapa stadia perkembangan umbi. Percobaan dilakukan dengan rancangan acak lengkap dengan faktor tunggal, yaitu vernalisasi pada beberapa stadia perkembangan umbi. Perlakuan terdiri atas umbi tanpa vernalisasi $\left(\mathrm{S}_{0}\right)$, vernalisasi pada stadia embrio $\left(\mathrm{S}_{1}\right)$, vernalisasi pada stadia tumbuh tunas $1 \mathrm{~cm}\left(\mathrm{~S}_{2}\right)$, dan vernalisasi pada stadia tumbuh tunas $2 \mathrm{~cm}\left(\mathrm{~S}_{3}\right)$. Vernalisasi 
dilakukan dengan cara menyimpan umbi bawang merah dengan beberapa stadia pertumbuhan pada suhu $8{ }^{\circ} \mathrm{C}$ selama 6 minggu. Percobaan dilakukan dengan 6 ulangan dengan masing-masing 9 tanaman dalam setiap satuan percobaan.

Umbi ditanam pada media tanam yang berupa campuran antara tanah dan pupuk kandang (1 : 1). Sebelum penanaman umbi bawang merah direndam dalam larutan fungisida dengan bahan aktif benomil 50\% dengan konsentrasi $2 \mathrm{~g} \mathrm{~L}^{-1}$ selama 15 menit. Pemupukan yang diberikan berupa pupuk NPK mutiara (15:15:15) dengan dosis $600 \mathrm{~kg} \mathrm{ha}^{-1}$ atau $2.4 \mathrm{~g}$ per polibag.

Pengamatan terhadap karakter bobot awal umbi dilakukan dengan menimbang umbi sebelum tanam, sedangkan karakter tinggi tanaman, jumlah anakan, jumlah daun diamati saat tanaman berumur 5 minggu setelah tanam (mst). Pengamatan terhadap waktu berbunga, waktu seludang pecah, jumlah umbel, panjang umbel, dan diameter umbel dilakukan saat $75 \%$ tanaman sudah menunjukkan karakter tersebut. Pengamatan terhadap persen tanaman berbunga dilakukan dengan menghitung jumlah tanaman yang berbunga dibagi dengan jumlah tanaman tiap perlakuan dalam setiap ulangan. Pengamatan terhadap jumlah umbi, diameter umbi, bobot segar umbi dilakukan saat panen. Data penelitian dianalisis dengan analisis sidik ragam (ANOVA) dan diuji lanjut berdasarkan Duncan's multiple range test (DMRT) dengan tingkat kepercayaan 95\%, dengan menggunakan program SAS versi 9.1. Analisis korelasi Pearson menggunakan perangkat lunak R paket "agricolae" (R versi 3.2.2 http://www.r-project.org/).

Analisis metabolomik menggunakan sampel daun bawang merah pada umur 5 minggu setelah tanam. Sampel diambil di pagi hari, dengan cara memotong daun segar yang tumbuh di dekat tangkai bunga dengan ukuran $\pm 7 \mathrm{~cm}$ per tanaman. Analisis metabolomik menggunakan instrumen GC-MS pirolisis (GCMS-QP2010 system, Shimadzu Japan) yang dihubungkan dengan mass spectrometer detector. Sampel dimasukkan ke dalam ruang kuarsa di unit pirolisa. Gas helium digunakan sebagai carrier gas dengan mode aliran konstan pada $0.85 \mathrm{ml}$ per menit. Kolom analisis adalah Rt x 5 MS, dengan panjang $60 \mathrm{~m}$, ketebalan $0.25 \mu \mathrm{m}$, dan diameter $0.25 \mathrm{~mm}$. Suhu awal kolom adalah $50{ }^{0} \mathrm{C}$, yang secara bertahap meningkat sebesar $10{ }^{0} \mathrm{C}$ sampai $280{ }^{\circ} \mathrm{C}$. Detektor spektrometer massa digunakan untuk mendeteksi senyawa saat dilepaskan dari kolom dengan suhu detektor $200{ }^{\circ} \mathrm{C}$.

Identifikasi komponen non-target metabolit dilakukan dengan mencocokkan spektrum massa dengan yang tersedia pada database WILEY7 LIB. Nama putatif senyawa tersebut dikonfirmasikan dengan menggunakan database online PubChem di NCBI (https: //pubchem.ncbi. nlm.nih.gov/), chemicalbook database (http://www.chemicalbook.com), dan NIST webbook database (http: //webbook.nist. gov/). Dataset dari nilai konsentrasi masingmasing senyawa putatif ditransformasikan dengan $\log 2$ untuk mendapatkan data yang dinormalisasi. Matriks data dari non-target metabolit bawang merah pada masing-masing perlakuan vernalisasi dianalisis dengan menggunakan paket Metabolomik pada software R. Paket metabolomik dioperasikan untuk membangun hierarchical cluster analysis (HCA) dan memvisualisasikan heatmap dengan dendrogram. HCA menggunakan metode jarak jauh Euclidean (euclidean distance method) dan metode aglomerasi keterkaitan lengkap (complete linkage agglomerative method).

\section{HASIL DAN PEMBAHASAN}

Bawang merah yang ditanam menunjukkan pertumbuhan yang cukup baik. Hasil analisis ragam menunjukkan bahwa perlakuan vernalisasi pada stadia perkembangan umbi memberikan pengaruh yang berbeda sangat nyata terhadap karakter bobot awal umbi, tinggi tanaman, diameter umbel, dan persen berbunga dan menunjukkan pengaruh yang tidak berbeda nyata terhadap karakter lainnya. Hasil uji DMRT pada Tabel 1 menunjukkan pula bahwa umbi yang tidak divernalisasi memiliki respon yang lebih rendah dibandingkan dengan umbi yang mendapat vernalisasi pada stadia awal (stadia embrio dan tunas $1 \mathrm{~cm}$ ). Umbi tanpa vernalisasi memiliki karakter morfologi dan pembungaan yang relaif sama dengan umbi yang divernalisasi pada stadia lanjut (tunas $2 \mathrm{~cm}$ ).

Perlakuan vernalisasi secara signifikan meningkatkan jumlah umbel, diameter umbel dan persen berbunga, tetapi menunjukkan pengaruh yang berbeda tidak nyata pada 
karakter-karakter kuantitatif pembungaan lainnya. Menurut Brewster (2008), vernalisasi dapat menginduksi pertumbuhan generatif dibandingkan pertumbuhan vegetatif. Pada umbi yang tidak divernalisasi memiliki jumlah umbel yang lebih kecil (1.16 umbel) dibandingkan dengan umbi yang divernalisasi (1.53-2.08 umbel), serta diameter umbel yang lebih kecil $(46.83 \mathrm{~mm})$ dibandingkan tanaman yang mendapat perlakuan vernalisasi (53.69$56.68 \mathrm{~mm})$. Hal ini menunjukkan bahwa perlakuan vernalisasi mampu mendorong kemampuan berbunga tanaman bawang merah.

Perlakuan vernalisasi juga menunjukkan persen berbunga tanaman yang lebih besar (70.37-79.63\%) dibandingkan tanaman yang tidak divernalisasi (29.63\%). Sejalan dengan penelitian Mollah et al. (2015), bahwa perlakuan tanpa vernalisasi menyebabkan jumlah umbel, diameter umbel bawang menjadi lebih rendah dibandingkan bawang yang diperlakuan dengan vernalisasi $10-15{ }^{\circ} \mathrm{C}$. Perbedaan stadia tumbuh menyebabkan perbedaan toleransi terhadap lingkungan, sehingga tanaman harus meregulasi proses pertumbuhan dan perkembangannya (Auge $e t$ al., 2017). Kemampuan berbunga dipengaruhi berbagai faktor lingkungan dan faktor genetik tanaman (Yang et al., 2016).

Peningkatan persen berbunga karena perlakuan vernalisasi tidak hanya terjadi pada tanaman bawang merah, penelitian Ami et al. (2013) pada bawang bombai menunjukkan vernalisasi dengan suhu rendah $5 \pm 1{ }^{\circ} \mathrm{C}$ dapat meningkatkan persentase pembentukan bunga secara signifikan yaitu $99.14 \%$ pada 52 hst dan $99.43 \%$ pada 57 hari setelah tanam. Elsiddig et al. (2015) menunjukkan perlakuan vernalisasi dengan suhu $4-5{ }^{\circ} \mathrm{C}$ selama 90 hari atau lebih merupakan faktor utama dalam menginduksi pembungaan bawang bombai kultivar Texas Grano. Penelitian McCormick et al. (2014) menunjukkan bahwa perlakuan vernalisasi pada suhu $4{ }^{0} \mathrm{C}$ selama $4-12$ minggu memberikan pengaruh positif terhadap proses pembungaan tanaman bit merah. Berbeda dengan penelitian Jasmi et al. (2013) yang menunjukkan perlakuan vernalisasi pada bawang merah tidak mampu menginduksi pembungaan di dataran rendah, tetapi dapat meningkatkan indeks panen. Penelitian Wu et al. (2016) menunjukkan bahwa vernalisasi menyebabkan berkurangnya pertumbuhan vegetatif tanaman bawang putih. Amasino et al. (2016), vernalisasi dibutuhkan untuk proses perkembangan bunga. Bertambahnya persen berbunga bawang merah diduga merupakan hasil peningkatkan aktifitas pembelahan sel tanaman karena mendapat perlakuan vernalisasi. Hal inilah yang menyebabkan perlakuan vernalisasi mampu meningkatkan kemampuan berbunga bawang merah yang ditunjukkan dengan peningkatan karakter diameter umbel dan persen berbunga bawang merah.

Analisis korelasi dapat menjelaskan keeratan hubungan antara dua karakter atau lebih. Hasil penelitian menunjukkan terdapat korelasi positif yang sangat nyata antara saat muncul umbel dengan saat umbel pecah (75\%), dan antara jumlah umbel dengan panjang umbel (73\%) (Tabel 2). Semakin lama waktu yang dibutuhkan untuk membentuk umbel, semakin lama pula waktu yang dibutuhkan untuk umbel pecah. Hal ini berkaitan dengan proses pembentukan dan pematangan bunga dalam umbel.

Tabel 1. Keragaman morfologi dan kuantitatif pembungaan bawang merah dengan perlakuan vernalisasi pada stadia perkembangan umbi. Umbi tanpa vernalisasi $\left(\mathrm{S}_{0}\right)$, vernalisasi stadia embrio $\left(S_{1}\right)$, vernalisasi stadia tunas $1 \mathrm{~cm}\left(S_{2}\right)$, vernalisasi stadia tunas $2 \mathrm{~cm}\left(S_{3}\right)$

\begin{tabular}{cccccc}
\hline Perlakuan & \multicolumn{5}{c}{ Karakter } \\
\cline { 2 - 6 } & $\begin{array}{c}\text { Bobot Awal } \\
\text { Umbi }(\mathrm{g})\end{array}$ & $\begin{array}{c}\text { Tinggi } \\
\text { Tanaman }(\mathrm{cm})\end{array}$ & $\begin{array}{c}\text { Jumlah Umbel } \\
\text { (umbel) }\end{array}$ & $\begin{array}{c}\text { Diameter } \\
\text { Umbel }(\mathrm{mm})\end{array}$ & $\begin{array}{c}\text { Persentase } \\
\text { Berbunga (\%) }\end{array}$ \\
\hline $\mathrm{S}_{0}$ & $5.89 \mathrm{a}$ & $43.66 \mathrm{a}$ & $1.16 \mathrm{~b}$ & $46.83 \mathrm{~b}$ & $29.63 \mathrm{~b}$ \\
$\mathrm{~S}_{1}$ & $3.78 \mathrm{~b}$ & $43.46 \mathrm{a}$ & $2.08 \mathrm{a}$ & $56.68 \mathrm{a}$ & $70.37 \mathrm{a}$ \\
$\mathrm{S}_{2}$ & $3.01 \mathrm{c}$ & $41.44 \mathrm{ab}$ & $1.76 \mathrm{ab}$ & $54.90 \mathrm{a}$ & $79.63 \mathrm{a}$ \\
$\mathrm{S}_{3}$ & $2.71 \mathrm{c}$ & $40.72 \mathrm{~b}$ & $1.53 \mathrm{ab}$ & $53.69 \mathrm{a}$ & $40.74 \mathrm{ab}$ \\
\hline
\end{tabular}

Keterangan: * berbeda nyata $(\mathrm{P}<5 \%), * *=$ berbeda sangat nyata $(\mathrm{p}<1 \%)$, angka yang diikuti huruf yang sama pada kolom yang sama artinya tidak berbeda nyata berdasarkan uji DMRT pada taraf $\alpha=5 \%$. 
Menurut Avarez-Buylla et al. (2010), semua jaringan yang terdapat pada organ bunga tersusun berdasarkan pola pembentukannya dan laju pembelahan sel pada jaringan meristem. Proses pecahnya umbel akan sangat berkaitan dengan proses pematangan organ bunga lainnya di dalam umbel. Keeratan hubungan antara beberapa karakter morfologi dengan persen berbunga bawang merah menjadi indikator yang sangat penting dalam menentukan pilihan karakter seleksi yang tepat.

Hasil analisis korelasi antar karakter morfologi terhadap persen berbunga bawang merah menunjukkan bahwa terdapat korelasi yang sangat nyata pada karakter jumlah umbel (48\%), dan diameter umbel $(70 \%)$. Semakin besar jumlah umbel dan diameter umbel akan semakin meningkatkan persen berbunga bawang merah. Dengan demikian, karakter jumlah umbel dan diameter umbel dapat digunakan sebagai karakter seleksi untuk peubah persen berbunga bawang merah. Analisis keeratan hubungan diantara karakterkarakter kuantitatif sangat penting untuk menduga kemungkinan seleksi dari dua karakter atau lebih, dan untuk mengevaluasi pengaruh seleksi dari karakter-karakter sekunder terhadap karakter utama (Ezeaku dan Mohammed, 2006).

Sebanyak 104 senyawa metabolit spesifik bawang merah genotipe Bima Brebes diidentifikasi oleh instrumen GC-MS. Hasil analisis klaster hierarki yang divisualisasikan dengan heatmap metabolit spesifik, berhasil mengelompokkan bawang merah menjadi tiga kelompok berdasarkan perlakuan vernalisasi yang diberikan (Gambar 1).

Analisis klaster hierarki yang divisualisasikan dengan heatmap metabolomik menjelaskan distribusi pengelompokan senyawa metabolit spesifik pada setiap perlakuan vernalisasi. Terdapat 16 metabolit spesifik bawang merah tanpa perlakuan vernalisasi, 19 metabolit spesifik dengan vernalisasi stadia embrio dan stadia tunas $2 \mathrm{~cm}$, serta terdapat 11 metabolit spesifik pada vernalisasi umbi stadia tunas $1 \mathrm{~cm}$. Umbi tanpa vernalisasi dan dengan vernalisasi stadia tunas $2 \mathrm{~cm}$ menunjukkan profil metabolomik yang sama. Vernalisasi pada stadia tumbuh yang lebih awal (embrio) menunjukkan variabilitas metabolomik yang relevan.

Tabel 2. Nilai koefisien korelasi Pearson antar karakter morfologi bawang merah dengan perlakuan vernalisasi pada stadia tumbuh umbi

\begin{tabular}{|c|c|c|c|c|c|c|c|c|c|c|c|c|}
\hline Karakter & TT & JD & JA & SMU & $\mathrm{JU}$ & SUP & $\mathrm{PU}$ & DU & BBUi & JUi & DUi & PB \\
\hline Bobot awal & $0.53^{* *}$ & 0.04 & -0.14 & -0.11 & -0.26 & -0.00 & 0.09 & $-0.63^{* *}$ & 0.09 & 0.34 & $-0.18^{*}$ & -0.38 \\
\hline Tinggi tanaman & & 0.35 & 0.08 & -0.37 & 0.09 & -0.31 & 0.36 & -0.10 & -0.01 & 0.25 & -0.03 & -0.06 \\
\hline Jumlah daun & & & $0.63^{* *}$ & -0.39 & 0.26 & $-0.45^{*}$ & 0.13 & 0.29 & -0.10 & 0.00 & 0.10 & 0.31 \\
\hline Jumlah akar & & & & -0.38 & -0.03 & $-0.40^{*}$ & -0.02 & 0.20 & -0.19 & -0.10 & 0.29 & 0.38 \\
\hline $\begin{array}{l}\text { Saat muncul } \\
\text { umbel }\end{array}$ & & & & & -0.28 & $0.75^{* *}$ & -0.37 & -0.04 & -0.05 & -0.17 & -0.37 & -0.18 \\
\hline Jumlah umbel & & & & & & $-0.45^{*}$ & $0.73^{* *}$ & $0.59^{* *}$ & -0.24 & -0.28 & 0.09 & $0.48^{* *}$ \\
\hline $\begin{array}{l}\text { Saat umbel } \\
\text { pecah }\end{array}$ & & & & & & & $-0.54^{* *}$ & -0.25 & 0.23 & 0.16 & -0.15 & -0.30 \\
\hline Panjang umbel & & & & & & & & 0.20 & -0.11 & -0.23 & 0.23 & 0.24 \\
\hline Diameter umbel & & & & & & & & & -0.20 & $-0.51^{* *}$ & 0.12 & $0.70^{* * *}$ \\
\hline $\begin{array}{l}\text { Bobot basah } \\
\text { umbi }\end{array}$ & & & & & & & & & & $0.53^{* *}$ & $0.45^{* *}$ & -0.21 \\
\hline Jumlah umbi & & & & & & & & & & & -0.05 & -0.37 \\
\hline Diameter umbi & & & & & & & & & & & & 0.27 \\
\hline
\end{tabular}

Keterangan: TT= Tinggi tanaman; JD= Jumlah daun; JA= Jumlah akar; SMU= Saat muncul umbel; JU= Jumlah umbel; $\mathrm{SUP}=$ Saat umbel pecah; $\mathrm{PU}=$ Panjang umbel; DU= Diameter umbel; BBUi= Bobot basah umbi; JUi= Jumlah umbi; DUi= Diameter umbi; $\mathrm{PB}=$ Persen berbunga. $*=$ berkorelasi nyata pada taraf $5 \%$, **= berkorelasi sangat nyata pada taraf $1 \%$. 


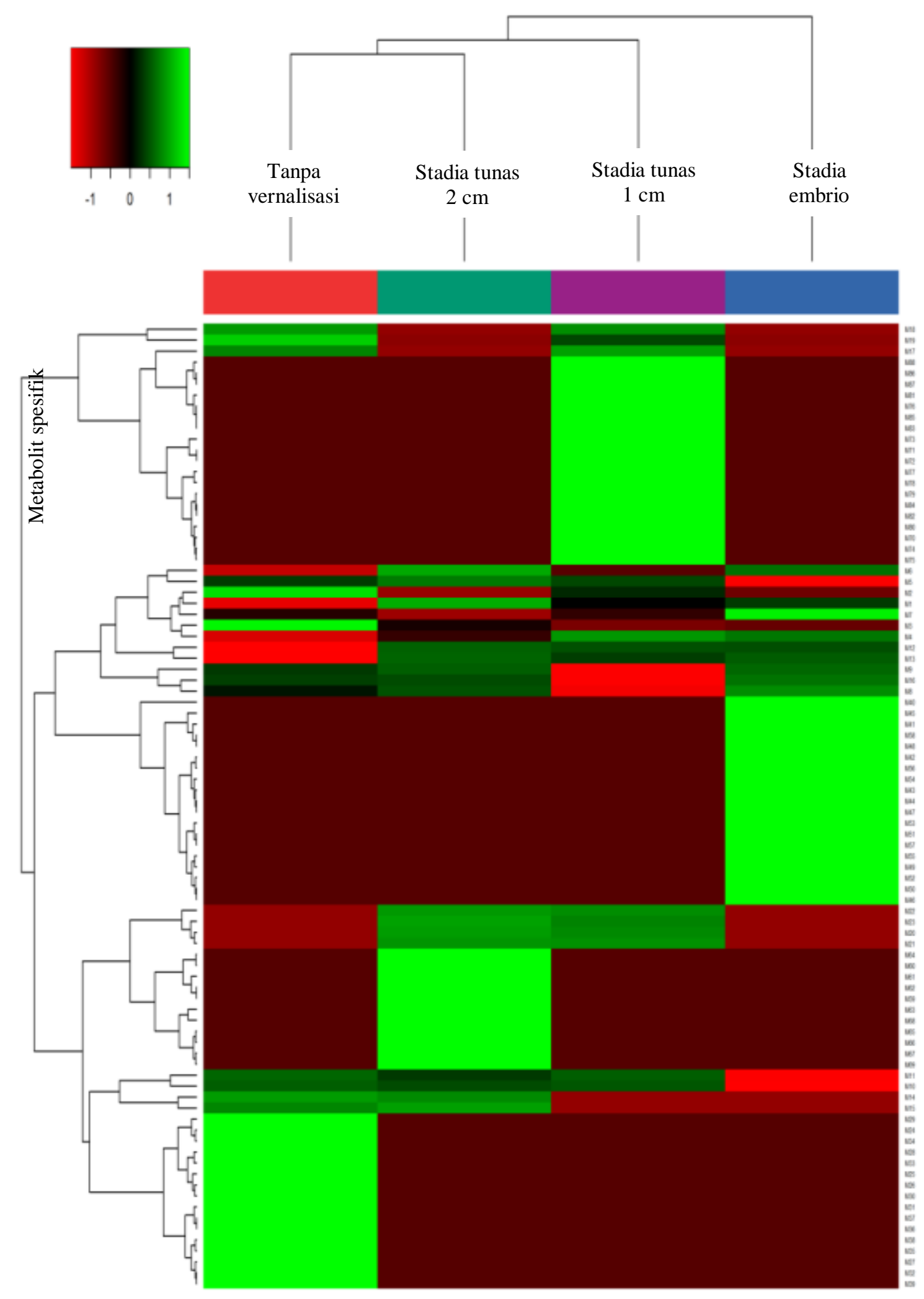

Gambar 1. Heatmap dari 104 metabolit dalam bawang merah genotipe Bima Brebes. Matriks dengan kode warna mewakili nilai rata-rata intensitas metabolit genotipe bawang merah 'Bima Brebes'. Warna merah = konsentrasi yang rendah, hitam = konsentrasi rata-rata, hijau = konsentrasi tinggi. Data metabolit telah diubah menjadi $\log 2$ dari rata-rata tengah. 
Metabolit spesifik pada umbi tanpa vernalisasi $\left(\mathrm{S}_{0}\right)$ didominasi oleh senyawa organosulfur, volatil, dan asam lemak. Analisis metabolomik mampu mengidentifikasi senyawa kimia yang sangat beragam dari senyawa anorganik ionik hingga karbohidrat hidrofilik, alkohol dan keton yang mudah menguap, asam amino dan non-amino, lipida hidrofobik, dan produk alami yang kompleks (Villas-Boas et al., 2005). Adanya konsentrasi senyawa alkil aldehida yang lebih tinggi pada umbi yang tidak divernalisasi disebabkan karena adanya akumulasi senyawa-senyawa volatil tersebut pada jaringan vegetatif tanaman.

Pada umbi yang divernalisasi, senyawa metabolit sekunder lebih didominasi oleh senyawa phytol yang berperan dalam meningkatkan kemampuan reproduksi tanaman. Selain itu, heatmap mengidentifikasi senyawa dengan aroma yang kuat seperti azetidine, benzonitrile, pyrrolidine, pentanedioic acid, heptanal, dan ambrettolide sebagai senyawa yang paling representatif pada perlakuan ini. Bawang merah dengan perlakuan vernalisasi pada stadia tunas $1 \mathrm{~cm} \quad\left(\mathrm{~S}_{2}\right)$ didominasi oleh minyak esensial dengan aroma dan anestesi yang kuat. Vernalisasi pada stadia ini menghasilkan peningkatan senyawa 2propanone yang merupakan senyawa volatil keton. Senyawa ini umumnya merupakan salah satu senyawa yang menjadi indikator yang ditemui saat tanaman memasuki fase reproduksi.

Bawang merah yang divernalisasi pada stadia tunas $2 \mathrm{~cm}\left(\mathrm{~S}_{3}\right)$ yang didominasi oleh nitrogen dan senyawa volatil. Tanaman yang divernalisasi pada stadia ini juga mengandung organosulfur dan sumber nitrogen seperti nitrogen oxide, propylene sulfide, 4H-1,2,4Triazol-3-amine, 4-methyl-, benzyl cyanide, dan tetradecanamideSenyawa organik ini termasuk dalam kelompok senyawa thiol, yang merupakan cairan tak berwarna dan memiliki aroma yang kuat. Lokke et al. (2012) melaporkan bahwa umbi bawang memiliki senyawa propanethiol konsentrasi tertinggi dengan aktifitas aroma 20 kali lebih tinggi dari pada dipropyl disulfide.

Perlakuan vernalisasi mampu meningkatkan konsentrasi metabolit sekunder pada bawang merah dibandingkan umbi yang tidak divernalisasi. Perlakuan vernalisasi pada umbi bawang merah mengakibatkan kondisi stres dan dapat memicu eskalasi metabolit sekunder. Johnston et al. (2007) melaporkan bahwa perlakuan suhu rendah biasanya menginduksi pembentukan reactive oxygen species (ROS). Hasil penelitian menunjukkan bahwa metabolit sekunder sebagai komponen rasa dan aroma teridentifikasi lebih tinggi pada umbi tanpa vernalisasi dan umbi yang divernalisasi pada stadia akhir (stadia tunas $2 \mathrm{~cm}$ ) dibandingkan stadia embrio. Wu et al. (2016) melaporkan bahwa respon terhadap vernalisasi bervariasi di antara tanaman bawang putih dari berbagai umur, meskipun diberikan perlakuan yang sama. Hal ini disebabkan karena komposisi metabolit ditentukan oleh fungsi kompleks dari berbagai proses regulasi di dalam sel (VillasBoas et al., 2005). Kemajuan dalam analisis metabolomik telah memberi kontribusi pada peningkatan kualitas program pemuliaan dan bioteknologi tanaman. Profil metabolit yang dideteksi dengan menggunakan instrumen yang sensitif dan selektif merupakan cara penting untuk mengevaluasi senyawa-senyawa potensial pada tanaman, serta keamanan dan khasiatnya (Wu et al., 2013).

\section{KESIMPULAN}

Vernalisasi yang diberikan pada stadia awal perkembangan umbi (stadia embrio dan stadia $1 \mathrm{~cm}$ tunas) terbukti lebih efektif dalam menerima perlakuan vernalisasi untuk menginduksi kemampuan berbunga bawang merah dibandingkan perlakuan lainnya. Vernalisasi pada stadia tunas $2 \mathrm{~cm}\left(\mathrm{~S}_{3}\right)$ merupakan stadia yang kurang efektif terhadap perlakuan vernalisasi, stadia ini memiliki karakter yang sama dengan perlakuan tanpa vernalisasi $\left(\mathrm{S}_{0}\right)$. Hasil analisis korelasi menunjukkan bahwa karakter jumlah umbel dan diameter umbel memiliki korelasi positif yang sangat nyata terhadap persen berbunga bawang merah. Semakin besar jumlah umbel dan diameter umbel semakin meningkat persen berbunga bawang merah. Analisis metabolomik menghasilkan 104 metabolit spesifik dari 4 perlakuan vernalisasi, dan mengelompokkan bawang merah menjadi 3 kelompok stadia yang berbeda. Vernalisasi stadia awal dapat meningkatkan kandungan senyawa phytol dan 2-propanone yang dapat menjadi indikator penting yang menunjukkan tanaman telah memasuki fase reproduktif. Sebaliknya, umbi tanpa perlakuan vernalisasi dan vernalisasi pada stadia lanjut menghasilkan senyawa- 
senyawa organosulfur potensial sebagai senyawa aromatik khas bawang merah dan memiliki aktifitas sebagai antioksidan dan antimikroba.

\section{UCAPAN TERIMAKASIH}

Penelitian ini didanai melalui Hibah Penelitian Insentif Sistem Inovasi Nasional, Kementerian Riset dan Teknologi, Pendidikan Tinggi Tahun 2016.

\section{DAFTAR PUSTAKA}

Amasino, R.M. 2016. Vernalization pathways in different plant groups. Plant Physiology Preview. 1-30. www. plantphysiol.org. [24 Agustus 2017].

Ami, E.J., M.T. Islam, A.M. Farooque. 2013. Effect of vernalization on seed production of onion. Agriculture, Forestry and Fisheries. 2(6): 212-217.

Auge, G.A., L.K. Blair, H. Neville, K. Donohue. 2017. Maternal vernalization and vernalization-pathway genes influence progeny seed germination. New Phytologist. 1-13.

Alvarez-Buylla, E.R., M. Benítez, A. CorveraPoiré, A. Chaos-Cador, S. de Folter, A. Gamboa de Buen, A. Garay-Arroyo, B. García-Ponce, F. Jaimes-Miranda, R.V. Pérez-Ruiz, A. Piñeyro-Nelson, Y.E. Sánchez-Corrales. 2010. Flower Development. The Arabidopsis Book. American Society of Plant Biologists. 157.

Brewster, J.L. 2008. Onion and Oher Vegetables Alliums 2nd Edition. CABI Oxfordshire. UK. 432 hal.

Elsiddig, E.A.M., O.M. Elamin, M.E. Elkashif. 2015. Induction of flowering in texas early grano onion cultivar using vernalization and gibberellic acid under gezira state conditions, Sudan. Internl. J. of Sci. and Resch Publ. 5(9): 1-7.
Ezeaku, I.E., S.G. Mohammed. 2006. Character association and path analysis in grain sorghum. Afr. J. of Biotechnol. 5(14): 1337-1340.

Friesen, N., R.M. Fritsch, F.R. Blattner. 2006. Phylogeny and new intrageneric classification of Allium (Alliaceae) based on nuclear ribosomal DNA its sequences. Aliso. 22(1): 372-395.

Handerson, I.R., C. Shindo, C. Dean. 2003. The need for winter in the switch to flowering. Ann. Rev. of Genetic. 37: 371-392.

Jasmi, E. Sulistyaningsih, D. Indradewa. 2013. Pengaruh vernalisasi umbi terhadap pertumbuhan, hasil, dan pembungaan bawang merah (Allium cepa L. aggregatum group) di dataran rendah. Ilmu Pertanian. 16(1): 42-57.

Johnston, J.W., K. Harding, E.E. Benson. 2007. Antioxidant status and genotypic tolerance of ribes in vitro cultures to cryopreservation. Plant Science. 172(3): 524-534.

Lekshmi, N.C.J.P., S. Viveka, M.B. Viswanathan, G. Manivannan, T.M. Shobi. 2014. GC-MS characterization of volatile odorous compounds in Allium cepa. Nanobio Pharmaceutical Technology. 488-494.

Lokke, M.M., M. Edelenbos, E. Larsen, A. Feilberg. 2012. Investigation of volatiles emitted from freshly cut onions (Allium cepa L.) by real time proton - transfer reaction - mass spectrometry (PTR-MS). Sensors. 12(12): 16060-16076

McCormick, J.I., R.A. Goodger, R.J. Chynoweth. 2014. Cardinal temperatures and vernalisation requirements for a selection of vegetables for seed production. Agronomy New Zealand. 44: 71-83. 
Mnayer, D., A. Fabiano-Tixier, E. Petitcolas, T. Hamieh, N. Nehme, C. Ferrant, X. Fernandez, F. Chemat. 2014. Chemical composition, antibacterial and antioxidant activities of six essentials oils from the Alliaceae family. Molecules. 19: 2003420053.

Mollah, M.R.A., M.A. Ali, M. Ahmad, M.K. Hassan, M.J. Alam. 2015. Effect of planting dates on the yield and quality of true seeds of onion. International Journal of Applied Sciences and Biotechnology. 3(1): 67-72.

Nielsen, J. 2001. Metabolic Engineering. Applied Microbiology and Biotechnology. 55: 883-887.

Omar, S.H., N.A. Al-Wabel. 2010. Organosulfur compounds and possible mechanism of garlic in cancer. Saudi Pharmaceutical Journal. 18: 51-58.

Susanto, S., M. Melati, H. Sugeru 2016. Perbaikan pembungaan pamelo melalui aplikasi strangulasi dan zat pemecah dormansi. J. Hort. Indonesia. 7(3): 139145 .

Sumner, L.W., P. Mendes, R.A. Dixon. 2003. Plant metabolomics: Large-scale phytochemistry in the functional genomics era. Phytochemistry. 62(6): 817-836.
Tugizimana, F., L. Piater, I.A. Dubery. 2013. Plant metabolomics: A new frontier in phytochemical analysis. South African J. of Science. 109(5): 1-11.

Villas-Boas, S.G, S. Mas, M. Akesson, J. Smedsgaard, J. Nielsen. 2005. Mass spectrometry in metabolome analysis. Mass Spectrom. Rev. 24(5): 613-646.

Wu, H., O.J. Gu, S. Chen, X. Liu, Y. Zhou, X. Zhang, X. Xu. 2013. Recent developments in qualitative and quantitative analysis of phytochemical constituents and their metabolites using liquid chromatography-mass spectrometry. J of Pharmaceutical and Biomedical Analysis. 72: 267-291.

Wu, C., M. Wang, Y. Dong, Z. Cheng, H. Meng. 2016. Effect of plant age and vernalization on bolting, plant growth, and enzyme activity of garlic (Allium sativum L.). Scientia Horticulturae. 201: 295-305.

Yang, C., Y. Ye, C. Song, D. Chen, B. Jiang, Y. Wang. 2016. Cloning and functional identification of the AcLFY gene in Allium cepa. Biochemical and Biophysical Research Communications. 473: 1100-1105. 